\title{
Forward, Forward Option and No Hedging Which One is the Best for Managing Currency Risk?
}

\author{
Riko Hendrawan \\ Program of Magister Management Telkom University \\ Jl. Gegerkalong Hilir No. 47 Bandung, 40152, Indonesia
}

\section{ABSTRACT}

Keywords:

Derivative;

Forward; Forward

Option; Hedging

Bank Indonesia Regulation No.18/18/PBI/2016 concerning foreign exchange transactions against rupiah between banks and domestic parties, indicates that the importance of hedging for business actors in Indonesia. Based on the data of the rupiah exchange rate movement against the dollar from January 2006 to December 2016 shows that the fluctuation of the rupiah against the US dollar tends to weaken, although at some point the obser-

JEL: G13, G17 vation shows the strengthening of the rupiah against the US dollar. The purpose of this research is to assess impact of Forward, Forward Option and No Hedging Strategy for managing currency exposure between IDR to USD. Using data from January 2006-December 2016 taken from website of Bank Indonesia and Federal Reserve. Total 396 simulations, consists of 132 using Forward simulations, 132 using Forward Option simulations and 132 using No Hedging simulations. Findings from this research show that Forward Option was has no positive contribution in managing currency exposure, No Hedging Strategy has 36,36 percent positive contribution and forward contract has 72,73 percent positive contribution in managing currency exposure. Its means Forward Contract was better than Forward Option and No Hedging Strategies in managing currency exposure
\end{abstract}

\section{ABSTRAK}

Kata kunci:

Derivatif; Forward;

Opsi Forward;

Hedging
Peraturan Bank Indonesia NOMOR 18/18/PBI/2016, tentang transaksi valuta asing terhadap rupiah antara bank dengan pihak domestik, menunjukkan bahwa akan arti pentingnya lindung nilai (hedging) bagi para pelaku usaha di Indonesia. Berdasarkan data pergerakan kurs rupiah terhadap dolar periode Januari 2006 sampai Desember 2016 menunjukkan bahwa fluktuasi nilai tukar rupiah terhadap US dolar cenderung melemah, walaupun pada beberapa titik pengamatan menunjukkan penguatan nilai tukar rupiah terhadap US dolar. Tujuan Penelitian ini adalah untuk menguji dampak dari penerapan forward, forward option dan strategi no hedging dalam mengelola tekanan perubahan mata uang. Dengan menggunakan data nilai tukar mata uang dari bulan Januari 2006 hingga Desember 2016, data diperoleh dari website Bank Indonesia dan Federal Reserve. Menggunakan 396 simulasi yang terdiri dari 132 menggunakan kontrak Forward, 132 menggunakan kontrak opsi forward dan 132 tidak menggunakan no hedging. Hasil penelitian ini menunjukkan bahwa penggunaan kontrak Opsi Forward tidak memberikan hasil yang positif dalam pengelolaan risiko, tidak menggunakan no hedging berdampak positif sebesar 36,36 persen dan penggunaan forward kontrak berdampak positif sebesar 72,73 persen. Dari hasil penelitian ini menunjukkan bahwa forward kontrak lebih baik dibandingkan menggunakan kontrak opsi forward dan tidak menggunakan no hedging dalam mengelola risiko tekanan mata uang. 
The issuance of Bank Indonesia Regulation No.18/ 18/PBI/2016 on foreign exchange transactions against the rupiah between banks and domestic parties, shows that the importance of hedging for businesses in Indonesia. Based on the data of the rupiah exchange rate movement against the dollar from January 2006 to December 2016 on chart 1 below shows that the fluctuation of the rupiah against the US dollar tends to weaken, although at some point the observation shows the strengthening of the rupiah against US dollar. The rupiah is at the highest position at IDR 8,800 per US dollar on March 11, 2011 and the rupiah exchange rate was at the lowest level at IDR 14,300 per US dol- lar on June 17, 2015, while the average rupiah exchange rate of IDR 10,415 per US dollar during the period January 2006 to December 2016.

Furthermore, based on data of daily return on rupiah exchange rate against dollar from January 2006 to December 2016 in Figure 2 below shows that the strengthening and weakening of the rupiah against the US Dollar currency ranges from $10.42 \%$ to $15,07 \%$ per day.

Fluctuations in daily high returns reflecting the high volatility, as shown in Figure 2 above have an impact on exchange rate risk faced by businesses, or government. Bakshi \& Madan (2006), Li \& Zhao (2006), Glasserman \& Wu (2011) and

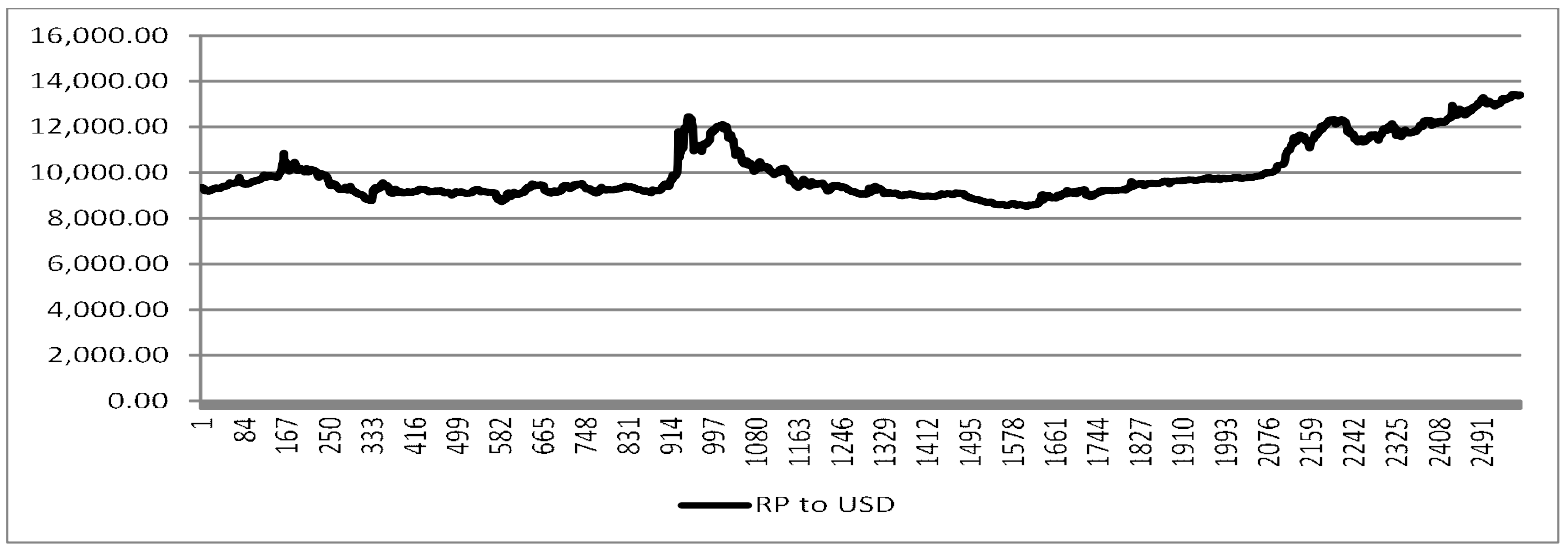

Source: Bank Indonesia (Processed)

Figure 1. Movement of IDR Exchange to US Dollars Period January 2006- December 2016

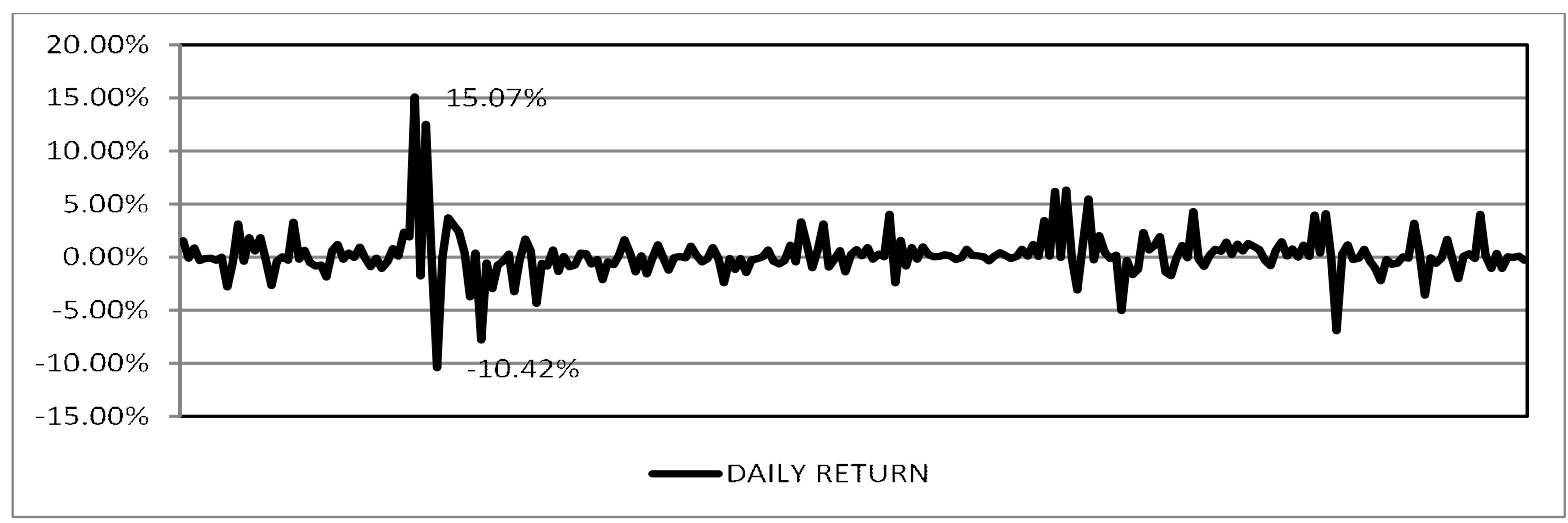

Source: Bank Indonesia (Processed)

Figure 2. Return To The Us Dollar Daily Rupiahs Period January 2006-December 2016 


\section{Jurnal Keuangan dan Perbankan | KEUANGAN}

Vol. 21, No. 3, Juli 2017: 356-365

Kourtis, Markellos \& Symeonidis (2016), carried out the impact of the volatility of an investment instrument, so that the need for a hedging instrument to manage the uncertainty of the movement of an investment instrument.

In the financial world, there are 4 of derivative instruments that can be used as a hedging tool that is forward, future's, swaps and options. From to four such instruments only option that is right while the three others are derivative instrument liabilities. Meaning the right of the option is the option buyer, either a put or a call has the right to execute a derivative instrument on the price level, the timing and amount agreed at the beginning. So that the hedging function of uncertainty rise or the decline of an underlying asset (underlying asset) that has the risk can be managed, for example the fluctuations exchange rate as presented in Figure 1 and 2 above.

Research on the importance of hedging against currency ever undertaken by Muff, Diacon \& Woods (2008) state that the functions performed for exposure hedging short-term nature and borrowing positions used to hedge long term. Vargas \& Kessakorn (2013) stated that the forward contract more effectively used than the option with a value of execution is above 1 percent, 5 percent and 10 percent above the value of the spot price in order to hedge the currency of international portfolio. Mittal (2015) states that in India firms under investigation using forward contracts should be used to minimize potential losses due to uncertainties in the future

Based on the above phenomenon in Figure 1 and 2 in which the change of the rupiah against the US dollar between -10.42 percent to 15.07 percent per day and previous research shows that derivatives can be used as a tool to hedge, in this study the authors aimed to evaluate, analyze and test derivative instruments (forward and forward option) in the framework of hedging rupiah currency against USD in 2006-2016. In previous stud- ies, the forward option has never been used as an instrument in the measurement of risk, so in this study forward option instrument used as a hedging instrument observed.

\section{Interest Rate Parity Theory}

Madura (2008), describes Interest Rate Parity Theory that the difference between the forward rate at the spot rate in a certain amount is the difference between interest rates between two countries. The formula is as follows:

$(1+$ If $)(1+$ f $)-1=$ Ih

Where:

Ih : interest rate of country of origin

If : foreign interest rates

F : Forward Premium

Based on the above equation 1, Madura (2008), the difference in interest rates between the two countries, leading to a rise or fall forward contract in the future compared with the spot value date. So advanced equation of equation 1, to learn Forward Premium are:

$(1+$ If $)(1+F)-1=$ Ih

$(1+$ If $)(1+\mathrm{F})=1+\mathrm{Ih}$

$(1+\mathrm{F})=(1+\mathrm{Ih}) /(1+$ If $)$

$\mathrm{F}=((1+\mathrm{Ih}) /(1+\mathrm{If}))-1$

\section{Derivative}

Hull (2009), explains that derivatives are investment instruments whose value depends on the underlying assets such as indexes, stocks, deposits, interest rates, currencies, commodities or other assets. Derivatives are contracts between two parties to exchange their assets in the future at an agreed price level, time and amount at the earliest. Function derivative is to hedge (hedging), arbitrage and speculation. 


\section{Forward}

Hull (2009), explained that the forward contract is an agreement (contract) which is compulsory between two parties to exchange assets in the future on the price level, the timing and amount agreed upon. Long position is a position forward contract to buy an investment instrument in the future on the price level, the timing and amount agreed upon. While short position is positive side forward contract to sell an investment instrument in the future on the price level, the timing and amount agreed upon. Hull (2009), states that the forward price formula is as follows:

$\mathrm{F}=$ So $\mathrm{x} \varepsilon^{1 \mathrm{t}}$.

Where:

F : price of forward contract

So : starting price of the underlying asset

å : constants

$r$ : interest rate

$\mathrm{t}$ : the duration of the contract takes place

Thus value of the forward contract is:

$\mathrm{f}=\mathrm{F}-\mathrm{K} \times \varepsilon^{1 \mathrm{t}}$

Where:

f : forward contract value

F : price of forward contract

$\mathrm{K}$ : redeemed price (execution)

å : constants

$\mathrm{r}$ : interest rate

$\mathrm{t}$ : the duration of the contract takes place

\section{Option and Forward Option}

Hull (2009), explains that the option is a contract between both parties (for premium buyers) and mandatory (for the seller of the premium) to exchange its future assets at the price, time and amount which has been agreed upon. Call option is the right to buy its assets in the future at the agreed price, time and quantity. Whereas a put option is the right to sell its assets in the future on the price level, while da $\mathrm{n}$ the number agreed upon. Hull (2009), states that the formula for calculating the value of the option is based on the formula of Black \& Scholes (1973), for call option is as follows:

$C=S N(d 1)-e^{-R_{f} T} X N(d 2)$

While the put option are as follows:

$P=X e^{-R_{f} T} N(-d 2)-S N(-d 1)$.

Where:

C : call option premium price

$\mathrm{P}$ : put option premium price

$S$ : The spot price of the underlying asset

$X$ : execution price / redeem

$\mathrm{T}$ : option maturity

$\mathrm{Rf}$ : risk-free interest rate /SBI

$\sigma \quad$ : variance of the underlying asset

$\mathrm{N}$ \{.\} : standard cumulative normal distribution

Eun \& Resni (2007) suggests based on equation 2, equation 5 and equation 6 , by approaching Interest Rate Parity, stating that the formula for forward option for call option are as follows (Eun \& Resnik, 2007):

$\mathrm{F}=$ So $x \in{ }^{\mathrm{r}}$ ind $^{\mathrm{r}}{ }^{\mathrm{r}} \mathrm{usa}^{\mathrm{t}}$ Equation (7)

So the formula for Call Forward Option is:

$\mathrm{C}=(\mathrm{F} \mathrm{N}(\mathrm{d} 1)-\mathrm{XN}(\mathrm{d} 2)) \varepsilon^{\mathrm{r}^{\mathrm{r}} \mathrm{ind}^{\mathrm{t}} \ldots . . . \text { Equation (8) }}$

While the formula for Put Forward Option is:

$\mathrm{P}=(\mathrm{XN}(-\mathrm{d} 2)-\mathrm{XN}(-\mathrm{d} 1)) \varepsilon^{\mathrm{r}}$ ind $^{\mathrm{t}}$...... Equation (9)

Where:

$\mathrm{r}$ ind $=$ risk-free interest rate in Indonesia

r usa = interest bung a risk-free in the US 


\section{Jurnal Keuangan dan Perbankan | KEUANGAN}

Vol. 21, No. 3, Juli 2017: 356-365

Papaioannou (2006), conducting research on American companies, argued that the use of derivative instruments in the management and control of risks due to changes in currency exchange rates becomes very important for these companies. Off-exchange derivatives transactions (over the counter), as much as 50 percent using forward currency instruments, 20 percent use the currency option and 10 percent using a currency swap.

Topaloglou, Vladimirou \& Zenios (2007), conducted a study of international portfolio from the perspective of American investors who have diversified currency assets, the study conducted using data exchange period May 1998-until November 2001. By using the Conditional Value at Risk Model (Cvar) that is dynamic and static, the research found that the forward contract is better than the protective put in asset management with diverse currencies.

Döhring (2008), conducted a study of 33 nonfinancial companies in Europe listed on the eurostoxx 50 index, of 33 companies, 32 companies used derivatives as a hedging tool, with details of 32 companies using forward contracts, 28 firms using option contracts in certain conditions and 22 companies using swaps, the results showed that the use of derivatives in this case of forward contracts and options are effective in reducing the pressure changes in currency exchange rates, minimal in the short term.

Muff, Diacon \& Woods (2008), conducted a study of 277 non-financial companies in the UK, the period of 1995-2001, the data obtained from the data stream. By using univariate and multivariate testing between companies that use derivatives and companies that do not use derivative hedging instruments, the results showed that the functions performed for exposure hedging shortterm nature and borrowing positions used to hedge long term.

Djenic, Avric, \& Barjaktarovic (2012), conducted a study of 33 banks operating in Serbia, from 33 banks as many as six banks offer derivative instruments are forward contracts as hedging instruments. Using the model of Value at Risk (Var), the results showed that the use of derivatives as a hedging tool, especially in the company, a large-scale enterprise becomes a very important factor in the management of currency pressure.

Vargas \& Kessakorn (2013), researching from the point of view of European investors by researching the movement of the Euro against the British Pound, the Euro against the USD, the Euro against the Chinese Yuan and the Euro against the Indian Rupee. Using put data execution of 1 percent, 5 percent and 10 percent above its spot value. And using Conditional Value at Risk (CvaR), the results showed that the forward contract more effectively used than the option with a value of execution is above 1 percent, 5 percent and 10 percent above the value of the spot price in order to hedge the currency international portfolio

Mittal (2015), conducted a study of four companies in India in the information technology sector using data from the financial statements of 20132014. Using data from the USD against the Indian Rupee spot on March 31, 2014 and actual data on June 30, 2014 the results showed that the forward contract should be used to minimize potential losses due to future uncertainties. Because even though it has the potential profit of 77.4 million rupees however, the potential loss is much greater than 472.14 Million rupees.

From various studies indicate that the main purpose of the derivative is not just for profit, but rather on hedging (hedging) due to uncertainty about the rise or fall of a currency. So, the potential risks experienced by investors will be more manageable with the use of derivatives as a hedging tool.

\section{METHODS}

The data in this study using the time span from 2006 to 2016 using the exchange rate of Bank 
Indonesia middle value obtained from the website of Bank Indonesia (www.bi.go.id). Risk-free interest rate (risk free rate) used is BI Rate (The period of 2006-up to July 2016) and BI 7 days report (August 2016-December 2016), to the interest rate in Indonesia, the use of BI 7 Report days since the period August 2016-December 2016, because BI rate is not eliminated, and replaced with BI 7-day report.

As for risk-free interest rate used in the United States is Treasury Bills (T-Bills) with a 3month period obtained from the website of the Federal Reserve (www.federalreserve.gov), the use of BI and BI 7-day repo in Indonesia and TTreasury Bill yields to synchronize the short number of risk-free assets with instruments forward and forward option.

Stages of data analysis techniques in this study are as follows: (1) Data movement of Rupiah against USD 2006-2016, BI Rate from 2006until July 2016 and for the period August 2016December 2016 using Repo BI 7 days and while the risk-free interest rate in the United States using the T-Bills during the years 2006-2016 for if and analyzed in this study. (2) Calculating the amount of the forward premium or discount to the forward contract, and calculate the amount of the premium for the call option contracts forward (forward options). (3) Forward contracts and forward option that is used by the 3-month period, so as to contract in January 2006 will end on March 31, 2006, the contract in February 2006 will expire on April 30, 2006 onwards, so that in a year there are 12 forward contracts, forward option, so in research with a span of 11 years, can do a test 264 forward contract options and forward option, whereby each forward contract option using call options with a value of execution above and below $5 \%$ of the value of the spot, as done by Vargas \& Kessakorn (2013). (1) For no hedging strategy there are 132 simulations, resulting in total observation of 396 observations. (2) The data used for testing forward, forward option and no hedging is secondary data every day of the month of March 2006 - up to March 2017, using the daily movement of bank Indonesia as a reference for determining the transaction price and calculation of the costs and benefits of each contract observed.

The analytical method used is Mittal (2015) by calculating the gain or loss of the use of forward, forward option and no hedging of any contract made se each calculated every year for 11 years, by comparing the results of the advantages or disadvantages of using no hedging, forward, and forward option as a hedging instrument with a contract term of 3 months.

\section{RESULTS}

\section{Forward Contract Research}

Based on the data analysis of differences in risk-free interest rate for 11 years from 2006-2016 in Table 1 below show that the approach based on interest rate parity theory, then during the years 2006-2016 rupiah will weaken ranged from 4.25 percent to 7.50 percent per year.

Table 1. Risk-Free Rate Differences in Indonesia and the United States Year 2006-2016

\begin{tabular}{cccc}
\hline Year & $\begin{array}{c}\text { T-Bills 3 } \\
\text { Months (\%) }\end{array}$ & $\begin{array}{c}\text { BI Rate } \\
\mathbf{( \% )}\end{array}$ & $\begin{array}{c}\text { IRP } \\
\mathbf{( \% )}\end{array}$ \\
\hline 2006 & 4.73 & 11.83 & 7.11 \\
2007 & 4.35 & 8.60 & 4.25 \\
2008 & 1.37 & 8.67 & 7.30 \\
2009 & 0.15 & 7.15 & 7.00 \\
2010 & 0.14 & 6.50 & 6.36 \\
2011 & 0.05 & 6.58 & 6.53 \\
2012 & 0.09 & 5.77 & 5.69 \\
2013 & 0.06 & 6.46 & 6.40 \\
2014 & 0.03 & 7.53 & 7.50 \\
2015 & 0.05 & 7.52 & 7.47 \\
2016 & 0.32 & 6.00 & 5.68 \\
\hline
\end{tabular}

However, based on the realization of exchange rates during 2006 - 2016 in table 2 below, there are 4 years that have different results be- 
Jurnal Keuangan dan Perbankan | KEUANGAN

Vol. 21, No. 3, Juli 2017: 356-365

Table 2. The Difference between the IRP Theory with Actual Exchange Rates Rupiah against USD in 2006 - 2016

\begin{tabular}{ccccr}
\hline Year & IRP (\%) & $\begin{array}{c}\text { Realization of } \\
\text { IDR/USD (\%) }\end{array}$ & \multicolumn{1}{c}{ Information } & Deviation (\%) \\
\hline 2006 & 7.11 & -7.91 & In contrast to theory & 15.02 \\
2007 & 4.25 & 5.24 & Appropriate theory & 0.99 \\
2008 & 7.30 & 16.86 & Appropriate theory & 9.56 \\
2009 & 7.00 & -14.16 & In contrast to theory & -21.15 \\
2010 & 6.36 & -3.63 & In contrast to theory & -10.00 \\
2011 & 6.53 & 1.02 & Appropriate theory & -5.51 \\
2012 & 5.69 & 5.97 & Appropriate theory & 0.29 \\
2013 & 6.40 & 25.85 & Appropriate theory & 19.45 \\
2014 & 7.50 & 1.62 & Appropriate theory & -5.88 \\
2015 & 7.47 & 10.59 & Appropriate theory & 3.12 \\
2016 & 5.68 & -3.32 & In contrast to theory & -9.01 \\
Average 11 Years & 6.48 & 3.47 & Appropriate theory & -3.01 \\
\hline
\end{tabular}

tween theory and realization, i.e. in 2006, 2009, 2010 and 2016, where in those years the rupiah is expected to decreased by 7.11 percent (2006), 7 percent (2009), 6.36 percent (2010) and 5.68 percent (2016) respectively, but in real terms the rupiah strengthened against USD with percentage of 7.91 percent, 14.16 percent, 3.63 percent and 3.32 percent respectively. If further examination biggest deviation occurred in 2009 amounted to 21.15 percent and the smallest deviation of 0.29 percent in 2012. But on average during the 11-year observation period indicated that based on the theory of interest rate parity rupiah will weaken by 6,48 percent, and the realization of rupiah weakened against the USD by 3.47 percent, or diverged by 3.01 percent.

\section{Results of Volatility Research and Its Implications If Without Hedging and Hedging Using Forward and Forward Option}

In Table 3 below, based on the volatility of changes in the exchange rate against the USD during the years 2006 to 2016 showed very mixed results. The highest volatility was in 2008 with a value of 74.21 percent per year, while the lowest volatility seen in 2010 amounted to 13.69 percent per year. The higher the volatility showed the higher the risk faced by investor or businesses that conduct transactions with the exchange rate against the USD, or vice versa.

Table 3. Volatility of Exchange Rate against USD Year 20062016

\begin{tabular}{ccc}
\hline Years & $\begin{array}{c}\text { Daily } \\
\text { Volatility (\%) }\end{array}$ & $\begin{array}{c}\text { Annual } \\
\text { Volatility (\%) }\end{array}$ \\
\hline 2006 & 1.66 & 26.35 \\
2007 & 1.43 & 22.74 \\
2008 & 4.67 & 74.21 \\
2009 & 2.54 & 40.25 \\
2010 & 0.86 & 13.69 \\
2011 & 1.28 & 20.27 \\
2012 & 1.14 & 18.11 \\
2013 & 2.23 & 35.36 \\
2014 & 1.78 & 28.18 \\
2015 & 1.95 & 30.96 \\
2016 & 1.56 & 24.72 \\
\hline
\end{tabular}

The impact of high and low volatility, using simulated 396-year contract for 2006-2016, where 132 is not conduct derivative transactions (no hedging), 264 conduct derivatives transactions consisting of 132 transactions and 132 transactions forward option indicates that during the years 20062016 (see Table 4 below) if no hedge only 4 years will occur favorable value for investors, namely in 2006, 2009, 2010 and 2016, even though the overall years of observation showed that if the hedge does not done on an average will incur losses. 
If the hedge is done by using contract forward will experience gains in over 8 years of 11 years of observation, that in 2006, 2007, 2009, 2010, $2011,2014,2015$, and 2016. Overall years of observation showed that if the hedge not done on an average will experience a profit. Whereas if the hedge by using a forward option, will suffer losses during the period of 2006-2016.

Table 4. Advantages and Kerugi's Near Hedging and No Hedging Rupiah against USD in 2006-2016

\begin{tabular}{crrr}
\hline Years & $\begin{array}{c}\text { No } \\
\text { Hedging }\end{array}$ & Forward & \multicolumn{2}{c}{$\begin{array}{c}\text { Forward } \\
\text { Option }\end{array}$} \\
\hline 2006 & 72 & 237 & $(822)$ \\
2007 & $(62)$ & 36 & $(623)$ \\
2008 & $(550)$ & $(372)$ & $(1.149)$ \\
2009 & 546 & 732 & $(1.695)$ \\
2010 & 98 & 244 & $(637)$ \\
2011 & $(32)$ & 113 & $(587)$ \\
2012 & $(175)$ & $(41)$ & $(450)$ \\
2013 & $(573)$ & $(405)$ & $(460)$ \\
2014 & $(206)$ & 18 & $(804)$ \\
2015 & $(228)$ & 24 & $(988)$ \\
2016 & 64 & 255 & $(1.119)$ \\
Average & $(95)$ & 76 & $(849)$ \\
\hline
\end{tabular}

\section{DISCUSSION}

From this study theoretically proves that the function of derivatives as a hedging tool, in this case is a forward contract provides empirical evidence which shows that 8 out of 11 years of observation shows 72.73 percent benefit (profit), if done in a protected value, whereas if it is not done hedges, only shows 4 of the 11 years of observation, or about 36.36 percent.

If studied further, when the mortgage crisis of 2008, although at a disadvantage, the forward contract also provides the smallest loss when compared to no hedging and options contracts forward. Likewise, in the year 2010 when the euro zone crisis, a forward contract gives the largest positive results when compared with no hedging and options contracts forward.
Theoretically the results of this study are in line with the results of research from Topaloglou, Vladimirou, \& Zenios (2007) where the forward contract is better than the option, Papaioannou (2006), Döhring (2008), Muff, Diacon, \& Woods (2008), Djenic, Avric, \& Barjaktarovic (2012) where the derivative proved capable and can be used to manage risk due to fluctuations in the exchange rate of a country and Mittal (2015) with an average proven benefits if derivatives used for hedging.

Implications practically, the results of this study, is the issuance of Bank Indonesia Regulation No.18/18/PBI/2016 on foreign exchange transactions against the rupiah between banks and domestic units, increasingly indicates that the importance of hedging for businesses in Indonesia, a mechanism needs to be created, so that businesses actors want to use derivative instruments for managing risks of currency exchange rate fluctuations.

From the results of this study also shows that not only hedging elements, but also a nominal profit can be achieved by investors or business actors by using derivative instruments in managing the risk of corporate currency or investment. It is shown that the cumulative forward contracts have the highest positive and cumulative outcomes when compared with no hedging and forward option contracts.

\section{CONCLUSIONS AND SUGGESTIONS}

\section{Conclusion}

This study aimed to evaluate, analyze and test derivative instruments (forward and forward option) in order to hedge Rupiah currency against USD in 2006-2016 in accordance with the issuance of Bank Indonesia Regulation No.18/18/PBI/ 2016 on foreign exchange transactions against the rupiah between banks and domestic parties, with conclusions as follows: for contract forward transactions, during the years 2006-2016 there were 4 


\section{Jurnal Keuangan dan Perbankan | KEUANGAN}

Vol. 21, No. 3, Juli 2017: 356-365

years have different results between theory and realization, namely in 2006, 2009, 2010 and 2016, which in those years rupiah is expected to be lower by 7.11 percent (2006), 7 percent (2009), 6.36 percent (2010) and 5.68 percent (2016), respectively, but the rupiah appreciated against USD by 7.91 percent, 14.16 percent, 3.63 percent and 3.32 percent. If further examination biggest deviation occurred in 2009 amounted to 21.15 percent and the smallest deviation of 0.29 percent in 2012. But on average during the 11-year observation period indicated that based on the theory of interest rate parity rupiah will weaken by 6.48 percent, and the realization of the rupiah weakened against USD by 3.47 percent, or deviate by 3.01 percent.

Using the simulation 396 contracts during the year 2006-2016, if no hedging only 4 years will occur favorable value for investors, namely in 2006, 2009,2010 , and 2016, even though the overall years of observation showed that if the hedge is not done average will incur losses. If hedging is done by using the Forward Contract will experience gains in over 8 years of 11 years of observation, that in 2006, 2007, 2009, 2010, 2011, 2014, 2015, and 2016. Overall years of observation showed that if the hedge is not done on average will experience an advantage. Meanwhile, if the hedging by using forward option, will suffer losses during the period 2006-2016. The results are consistent with the results of Topaloglou, Vladimirou, \& Zenios (2007) where the forward contract is better than the option, Papaioannou (2006), Döhring (2008), Muff, Diacon, \& Woods (2008), Djenic, Avric, \& Barjaktarovic (2012) where the derivative proved capable and can be used to manage risk due to fluctuations in the exchange rate of a country and Mittal (2015) with an average proven benefit if derivatives used for hedging.

\section{Suggestions}

The implications of this study theoretically proved that function as a hedging derivative, it is necessary to research the use of other instruments, e.g. swaps to manage currency risk. While the implication practically, the results of this study indicate that the importance of hedging for business people in Indonesia, it is necessary to make a mechanism, so that businesses managerial for using instruments derivative in managing the risk of fluctuations in exchange rates money.

\section{REFERENCES}

Bakshi, G.S., \& Madan, D. 2006, A Theory of Volatility Spreads. Management Science, 52(12): 1945-1956.

Bank Indonesia. 2016. Peraturan Bank Indonesia No.18/ 18/PBI/2016. Tentang Transaksi Valuta Asing terhadap Rupiah antara Bank dengan Pihak Domestik.

Black, F. \& Scholes, M. 1973. The Pricing of Option and Corporate Liabilities. Journal of Political Economy, 81(3): 637-654.

Djenic, M., Popovcic-Avric, S., \& Barjaktarovic, L. 2012. Importance of Forward Contracts in the Financial Crisis. Journal of Central Banking Theory and Practice, 2: 75-96

Döhring, B. 2008. Hedging and Invoicing Strategies to Reduce Exchange Rate Exposure: A Euro-Area Perspective. Economic Paper 229. Published by European Commission.

Eun, C.S. \& Resnick, B.G. 2007. International Financial Management. Boston: Published by McGraw-Hill/ Irwin.

Glasserman, P. \& Wu, Q. 2011. Forward and Future Implied Volatility. International Journal of Theoretical and Applied Finance, 14: 407-432.

Hull, J.C. 2009. Options, Futures, and Other Derivatives. 7th Edition. New Jersey: Published by Prentice Hall.

Kourtis, A., Markellos, R.N., \& Symeonidis, L. 2016. An International Comparison of Implied, Realized, and GARCH Volatility Forecasts. The Journal of Futures Market, 36(12): 1164-1193.

Li, H \& Zhao, F. 2006. Unspanned Stochastic Volatility: Evidence from Hedging Interest Rate Derivatives. Journal of Finance, 61: 341-378. 


\section{Forward, Forward Option and No Hedging Which One is the Best for Managing Currency Risk?}

Riko Hendrawan

Madura, J. 2008. International Financial Management. 9th Edition. South-Western Ohio: Published by Thomson.

Mittal, S. 2015. Hedging-An Effective Tool for Risk Management. International Multidisciplinary Research Journal, 2(1): 1-8.

Muff, T., Diacon, S., \& Woods, M. 2008. The Management of Currency Risk: Evidence from UK Company Disclosures. Centre for Risk \& Insurance Studies. Published by Nottingham University
Papaioannou, M. 2006. Exchange Rate Risk Measurement and Management: Issues and Approaches for Firms. Working Paper. Published by IMF.

Topaloglou, N., Vladimirou, H., \& Zenios, S.A. 2007. Controlling Currency Risk with Options or Forwards. Financial Engineering Handbook. Published by Springer.

Vargas, C.A \& Kessakorn, K. 2013. Forwards versus Options: Effectiveness in Hedging Currency Risk in International Portfolios. Project Degree. Published by Lund University. 